\title{
Editorial
}

\section{Engaging foreign publics in the age of Trump and Putin: Three implications of 2016 for public diplomacy}

Place Branding and Public Diplomacy (2016) 12, 243-246. doi:10.1057/s41254-016-0052-4

What in the world just hit us? As the hurricane that was 2016 disappears over our collective horizon, it leaves a toxic trail of death, disaster and dramatic political developments. The deaths were of both ordinary people and celebrities; the disasters were both man made and 'natural,' which are increasingly blending in any case, and the political developments would have been thought unbelievable even by their proponents as the year began. Britain's Brexit vote to leave the European Union in June 2016 and the victory of Donald J. Trump in the US presidential election in November were the two most obvious shocks, but the underlying currents of resurgent nationalism and intolerance seen in so many places were hardly less worrying. What then are the implications of the past year for the practice of public diplomacy? Three lessons loom large: people matter; facts matter; and places matter.

\section{PEOPLE MATTER}

In 2010 the founder and editor emeritus of this journal, Simon Anholt observed during the COP 16 Climate Summate in Cancun: 'There is only one superpower on the planet. That super power is public opinion. ${ }^{1} 2016$ showed how powerful and unpredictable that super power can be. All around the world populations seemed susceptible to a heady cocktail of pledges to build walls and make this or that country great again, especially when served with a twist of celebrity or unfiltered outspokenness. Consider the support marshalled by China's Xi, Russia's Putin or in smaller countries by Hungary's selfproclaimed illiberal democratic Prime Minister Viktor Orbán or the often outrageous Rodrigo Duarte, victor in the Philippine election of May 2016. Some publics seemed intent merely on not being taken for granted. In September, the electorate of Colombia unexpectedly rejected their government's peace treaty with the FARC rebels and derailed - one hopes only temporarily - years of progress towards resolution of a bitter civil war. In December, Italian voters rejected constitutional reform.

New media have given global publics an unprecedented role in determining their own and one another's destiny. This reality creates new responsibilities and priorities. One hundred and fifty years ago as Britain embarked on its first great expansion of the franchise the Victorian statesman, Robert Lowe (later first Viscount Sherbrooke) stressed an essential corollary - education reportedly noting, 'we must educate out masters.' The same is true today. How can 
we expect our own or other people's publics to make wise choices unless they have the educational foundations for those choices? In terms of public diplomacy, this gives renewed significance to educational exchanges, international educational and media development projects and high-quality public service international broadcasting in the best traditions of the BBC World Service or Voice of America. The need for an educated audience is all the more urgent when - as in 2016 - it has become increasingly difficult to tell the difference between fact and fantasy in the news media.

\section{FACTS MATTER}

Words are a reliable indicator of cultural climate a canary in our collective coal mine - just as the addition of 'selfie' to the Oxford English Dictionary was a key indicator for 2013 so the dictionary's embrace of 'post-truth' as the word for 2016 carries an important message. Part of the story of the past year is the salience of half-truths and outright lies in media generally and most especially on-line media. Western politics has struggled with media polarization, the bubbles created by social media and politicians claiming not only their right to their own opinion but their own facts for many years now; however, one striking feature of 2016 was that the circulation of fake news acquired an international dimension. 2016 was the year in which the mainstream western media noticed that one country had been actively involved in systematically distorting the news to serve its strategic objectives: Putin's Russia. While it is foolish to blame the Kremlin for the entire problem of 'fake news,' any response to media distortion or disinformation will need to include a response to Kremlin media.

The challenge of Kremlin media did not arrive overnight. Putin's Russia has been pushing back against what it considers the ubiquity of western messaging since at least the foundation of its satellite TV channel, Russia Today, in 2005. In was only with the Ukraine crisis in 2014 that the scale of the threat really dawned on western strategists. It became clear that Putin had successfully built a media machine in which a potent blend of propaganda and entertainment held his own people in thrall, and that its international elements including the Sputnik news agency and the re-branded satellite channel RT, were spreading stories which seemed crafted to sow doubt in the mind of the foreign audience. Kremlin media depicted a world in which all local authorities were failing; all alliances were bankrupt; all governments equally corrupt and nothing seemed knowable for sure. As the mist of misdirection thickened Putin deployed troops in Eastern Ukraine and seized Crimea. Analysts for governments in Russia's firing line identified an underlying theory behind Kremlin media practice and began to speak of 'hybrid warfare' in which the domination of the information space was as important as any kinetic movement of personnel or deployment of firepower. ${ }^{2}$ The exact role of Kremlin media and such surrogates as paid trolls and twitter-bots in boosting the respective causes of Trump, Brexit and the extremes of right and left in the west will be much debated in the months ahead, but the need is to respond. In former Soviet territory - places like the Baltic states, Ukraine, Moldova or Georgia - systematic responses to Kremlin media are already underway.

The most effective western responses to the challenge of Kremlin media fall across three categories of action: exposure of Russian disinformation, engagement with endangered populations and enhancement of local media. The exposure piece is being addressed by a range of actors from the independent Ukrainian website StopFake, to the European Union's External Action Service East Strategic Communication Task Force which publishes a regular Disinformation Review and a new website operated by Voice of America and Radio Free Europe called www.polygraph.info. ${ }^{3}$ For the engagement element, the existing tools of western public diplomacy, including exchanges, cultural work and international broadcasting - the British Council, Fulbright Scholarship and so forth - are being used to engage those societies most disrupted by Kremlin media, so to facilitate their own development and deepen their connections to the west. Finally, the efforts to enhance indigenous media in the contested areas are 
focusing on building entertaining, accurate and locally relevant alternatives to Kremlin material. A whitepaper by the European Endowment for Democracy in 2015 provided the blue print under the title 'Bringing Plurality and Balance to Russian Language Media'. ${ }^{4}$ Non-Kremlin channels working in the Russian language now have access to a news hub (based in Prague) to facilitate their sharing of content, with other resources coming online including enhanced training.

Such work needs to be expanded in 2017 (and funded at levels recommended by the European Endowment for Democracy) but it can only be the beginning, and does little to counter the damage of Kremlin media in our own back yard. The sad truth is that one reason that Kremlin media gains so much traction is that so much western media is falling short. The quest for audience and profit has too often obscured the duties of objectivity. The need to counter Kremlin media must also direct attention back to education. Improved media literacy and better journalism education are as much needed in the west as in the places bordering Russia. Western countries need to work hard to be better than the stereotypes of Kremlin propaganda. They've done it before. Sixty years ago during the Cold War President Eisenhower realized that the best defense against Kremlin stories of American racism was a concerted effort to extend Civil Rights to all American citizens. ${ }^{5}$ Today, as then, we in the west need to ensure that our democracies deliver on their promises and that we live up to our ideals. If we wish to speak of rights and values they should be framed as universal and identified with geography only to the extent that they are evident in our system.

The need to avoid playing into the Kremlin narrative also includes taking care to avoid demonizing the Russian people as a whole. Putin's appeal to the Russian speaking world rests on claims of western disrespect, arrogance and cultural imperialism. The west should not give him the gift of proving his point. One final thought is that if we accept that the Kremlin has weaponized information then next logical step should be to consider scope for negotiated control of that weapon. The final years of the Cold War saw what amounted to an information disarmament process. ${ }^{6}$ Surely, the time has come to resume this kind of conversation.

\section{PLACES MATTER}

The third lesson of 2016 may seem to swim against the current. While trends within nation states have been towards greater division with the politics of nostalgia, separation and even xenophobia gaining the upper hand, there has been a counter impulse towards greater cohesion in cities. One of the most striking political success stories of 2016 was the emergence of Sadiq Khan as a progressive, popular and coincidentally Muslim mayor of London. In the United States even as Donald Trump captured the White House, it was possible to see the country's largest cities - Chicago, New York, Los Angeles rallying around an opposite agenda of tolerance to migration as so-called sanctuary cities, and action against climate change. By the same token, in Eastern Europe, the best hope of countering the one-size-fits-all pan-Russian agenda peddled by the Kremlin lies in developing the distinct and unique multi-layered identities of the cities and regions in Russia's shadow. Citizens of a place like Narva on the Estonian/Russian border can be at the same time Russian speakers, Estonians and citizens of the European Union.

In recent years, cities have begun to see opportunities to sidestep the increasingly dysfunctional level of national government and connect with one another. City-based diplomatic fora are gaining prominence such as the $\mathrm{C} 40$ mayors meeting (which convened for the fourth time under the chairmanship of Paris Mayor Anne Hidalgo in Mexico in late November 2016) or the Global Parliament of Mayors, brainchild of the political theorist Benjamin Barber. ${ }^{7}$ The Global Parliament of Mayors held its first session in The Hague in September 2016 with seventy or so mayors from cities large and small from around the world gathered to explore common concerns of sustainability, democracy and diversity. The emergence of cities as international actors has an obvious connection to place branding. City branding has been one of the tools which 
internationally minded city governments have used to refine and project an identity distinct from that of their host nation-state. It is exciting to see city and place images deepening to offer more than just leisure or business experiences, but to include connection to deep values of culture or collective development which are closer to the kind of overarching values claimed by nation states in the past. An increase in city to city diplomacy - public and otherwise - linking places where pluralism is a daily reality is one of the ways in which the folly of unbridled nationalism can be held in check.

2017, therefore, comes with marching orders. Irrespective of political stripe or flag there is much to be done by academics and practitioners alike, engaging locally, nationally and internationally to promote our collective and mutual education, lay foundations of facts and helping to build strong places where our best selves can thrive. The practice and study of public diplomacy needs to be an important part of this process, and as citizens we should do what we can to ensure the health of our public diplomacy, cultural relations and international broadcasting agencies. The bottom line is, in 2017 as never before, public diplomacy matters.

\section{NOTES}

1 For a video of Anholt's remarks see https:// www.youtube.com/watch?v=zbKW7RDvz5s.
2 Influential voices included András Rácz, Russia's Hybrid War in Ukraine: breaking the enemy's ability to resist, The Finnish Institute of International Affairs, 2015, http://www.fiia. fi/en/publication/514/russia_s_hybrid_war_in_ ukraine/.

3 English language sites may be found at http:// www.stopfake.org/en/news/, https://eeas. europa.eu/headquarters/headquarters-home page/9443/disinformation-review_en and http://www.polygraph.info/.

4 https://www.democracyendowment.eu/news/ bringing-plurality-1/.

5 This process is documented in Mary Dudziak, Cold war civil rights: race and the image of American Democracy. Princeton University Press, 2000.

6 The US/Soviet information talks are discussed in Nicholas J. Cull, The Cold War and the United States Information Agency: American Propaganda and Public Diplomacy, 1945-1989. Cambridge University Press, 2008, Chapter 10.

7 On Barber's notion of a Global Parliament of Mayors see Benjamin Barber, If Mayors ruled the world, Yale University Press, 2013.

Nicholas J. Cull University of Southern California, Los Angeles, CA, USA E-mail: cull@usc.edu 